\title{
Urban and rural household energy consumption and deforestation patterns in Zaire province, Northern Angola: A landscape approach
}

\author{
Marina Padrão Temudo ${ }^{\mathrm{a}, *}$, Ana I.R. Cabral ${ }^{\mathrm{a}}$, Pedro Talhinhas ${ }^{\mathrm{b}}$ \\ ${ }^{a}$ Forest Research Centre (CEF), School of Agriculture, University of Lisbon, Tapada da Ajuda, 1349-017, Lisboa, Portugal \\ ${ }^{\mathrm{b}}$ Linking Landscape, Environment, Agriculture and Food (LEAF) Research Centre, School of Agriculture, University of Lisbon, Tapada da Ajuda, 1349-017, Lisboa, \\ Portugal
}

\section{A R T I C L E I N F O}

\section{Keywords:}

Africa

Household energy consumption

Rural and urban poor

Remote sensing

Fuelwood

Deforestation drivers

\begin{abstract}
A B S T R A C T
Angola has been labelled a "petro-state", since independence, due to its oil-wealth and the country's economic dependence on its revenues. Considering that oil availability and price could be a factor reducing deforestation and forest degradation through accelerating energy-transition, our objective was to study the energy consumption patterns and the role of woody biomass as a source of income of rural villagers and urban poor dwellers practicing agriculture, living in one of the oil-rich provinces. We used a "people and pixels" approach, combining interviews with households' heads with remote sensing analysis of land use/cover change. Our findings revealed that while kerosene is the main energy source for cooking and lighting in the city, in rural areas it is firewood and flashlights, respectively, and that the selling of firewood and/or charcoal is practiced by few households. Contrary to what has been reported about other Angolan regions and African countries, satellite imagery analysis showed that deforestation around Zaire province capital city and surrounding rural villages is comparatively small. Bearing in mind that the consumption of biomass for domestic household needs is reduced, other drivers of deforestation/forest degradation must be considered. Nonetheless, the high domestic use of kerosene contributes to the exhaustion of its limited global supplies and to increasing greenhouse gas emissions, disregarding the country's potential to produce renewable energy.
\end{abstract}

\section{Introduction}

In Sub-Saharan Africa, the large majority of the population use firewood and/or charcoal for domestic and economic activities (e.g., Hiemstra-van der Horst \& Hovorka, 2009; Bildirici \& Özaksoy, 2016, p. 288; Stoppok, Jess, Freitag, \& Erdmute, 2018), especially the poor (e.g., Adkins, Oppelstrup, \& Modi, 2012; Bone, Parks, Hudson, Tsinrinzeni, \& Willcock, 2017). While charcoal is usually described as the major energy source in most cities (e.g., Clancy, 2008; Mulenga, Tembo, \& Richardson, 2019; Ribot, 1999; Vollmer et al., 2017; Zulu \& Richardson, 2013), firewood is also mentioned as a regular source of energy for cooking in other urban locations (e.g., Guild \& Sheckleton, 2018; Hiemstra-van der Horst \& Hovorka, 2008; Mulenga et al., 2019; Odihi J. 2003; Schlesinger, Drescher, \& Shackleton, 2015; Schure, Levang, \& Wiersum, 2014). Angola is no exception and most households in the country are still dependent on traditional biomass to meet their cooking, heating and lighting needs (e.g., Cornelio, 2009; IEA, 2006; UNEP 2013). Much less than one fifth has access to grid electricity (UNEP 2013), and many use candles (IEA, 2006, p. 149). Additionally, public electricity supply is unreliable, and many families also have their diesel or petrol generator as a backup system (IEA, 2006).

According to some authors, most of the Angolan population rely on the use of firewood in rural areas and of charcoal in urban and periurban spaces (e.g., IEA, 2006, p. 20). Additionally, several authors state that charcoal production is leading to deforestation around the main cities (e.g., IEA, 2006, p. 141; Cornelio, 2009; Cabral, Vasconcelos, Oom, \& Sardinha, 2010) in a pattern similar to the one reported in other contexts (e.g., Clancy, 2008; Soussan, O'Keefe, \& Munslow, 1990). Indeed, this can be a major problem if we take into account that half of the country's population lives in cities and three-quarters in urban and peri-urban areas (Cain, 2007) and that production of charcoal is rather inefficient, not only in terms of labor inputs (e.g. Cornelio 2009) but also because it causes more deforestation than the use of firewood (e.g., IEA, 2006, pp. 144-145; Godfrey, Denis, Daniel, \& Akais, 2010). This problem is accrued by the role firewood gathering and/or charcoal production for trade can have as important sources of income for poor

\footnotetext{
* Corresponding author.

E-mail addresses: marinatemudo@gmail.com, marinatemudo@isa.ulisboa.pt (M.P. Temudo).
} 
households (e.g., Atyi, Poufun, Mvondo-Awono, Ngoungoure, \& Sufu, 2016; Clancy, 2008; Guild \& Sheckleton, 2018; Hiemstra-van der Horst \& Hovorka, 2009; Vollmer et al., 2017; Zulu \& Richardson, 2013).

Cornelio (2009: 34) asserts that in Huambo - an Angolan provincial capital - the main fuel used by urban households is charcoal (followed by firewood) and, as the wood stocks are now far from the city, many interviewees reported occasional hunger related to lack of access to fuel to cook their meals. However, the urban demand for fuelwood does not necessarily induces permanent deforestation and the growing urban population does not inevitably cause a wood fuel crisis (e.g., Clancy, 2008; Hansfort \& Mertz, 2011; Ribot, 1999; Swemmer, Mashele, \& Ndhlovu, 2019). During the wars, the area covered by forests increased (IEA, 2006, p. 141) and timber extraction fell dramatically after independence (Chiteculo, Hájek, \& Kubová, 2018). In addition, Angola is a large country and there are major differences among provinces and cities in terms of economic and infrastructures development and natural resources' wealth.

The post-independence Angolan land law of 1992 determined that only the state can own forests, except for small forested patches located in agricultural fields and pastures. In contrast to the law, the heads of the founding clans or lineages in rural villages perceive the land and its resources as being their own (Chiteculo et al., 2018). Legal pluralism, thus, when associated with a growing population, increased urbanization and lack of state capacity to control natural resources management can allow elite capture (both rural and urban, and frequently associated), deforestation and/or forest degradation and the destruction of the commons.

Bearing in mind that oil availability and price could be a factor reducing deforestation and forest degradation through accelerating the energy-transition, we conducted an exploratory study of the energy consumption patterns and the role of biomass as a source of income among rural villagers and urban poor dwellers practicing agriculture. Despite the growing body of literature on the many and intricate drivers of deforestation (e.g., Cabral et al., 2010; Konga et al., 2019; Sambou et al., 2015; Tadesse, Zavaleta, Shennan, \& FitzSimmons, 2014; Waroux \& Lambin, 2012), and on household energy consumption patterns in rural and urban settings (e.g., Adkins et al., 2012; Schure et al., 2014; Schlesinger, Drescher, A. and Shackleton 2015), to the best of our knowledge no empirical studies have directly addressed the link between households' sources of energy in an oil-rich region and land cover change assessed through remote sensing.

This study also introduces a more nuanced view to the energy transition debate by challenging the binary opposition between the "energy ladder" model - which assumes a linear progression from firewood to more modern fuels with increasing income (e.g., Barnes \& Floor, 1996) and the "multiple-fuel" or "fuel stacking" one - which assumes that fuel switching up the ladder is rare and households use other fuels without totally abandoning the traditional ones (e.g., Masera, Saatkamp, \& Kammen, 2000). We start by providing a short characterization of Zaire province and its capital Mbanza Kongo, followed by the description of the methodology. Using a "people and pixels" approach in the study of human-environment interactions (Liverman, Moran, Rindfus, \& Stern, 1998), the energy consumption patterns for cooking and lighting of poor households that practice agriculture - thus the ones more likely to use biomass as a source of energy and to become energy "stuck" (e.g., Masera et al., 2000) as they can collect it for free in their own fields and surroundings - is then combined with an exploratory analysis based on remote sensing data; thus, our objective was to gauge the extent to which deforestation is connected to household energy use and livelihood needs in a context of war refugees return, rapid urban expansion and roads infrastructures' development. Following from Tenerelli and Carver (2012), we argue that "there is a strong need to support energy policy decisions with spatially explicit evidence".

\subsection{Study site}

The Zaire province (Fig. 1) lies in the North of Angola, bordering with the Democratic Republic of Congo (DRC), the Atlantic Ocean, and Uige and Bengo provinces. It constitutes one of the country's oil-rich provinces, whose capital Mbanza Kongo has been recently nominated a UNESCO World Heritage site.

According to the Köppen-Geiger classification system, the climate is tropical savanna with dry winter (AW) and the mean annual rainfall is around $1300 \mathrm{~mm}$, distributed in two periods separated by a short dry spell (Castanheira Diniz, 2006, p. 63).

The vegetation is dominated by savanna scrublands and some dense humid forests, mostly along rivers, creeks, and gullies. There are anthropic forests composed by native species and mango, cola, safou, avocado, citrus, and guava trees in ancestral settlements (Castanheira Diniz, 2006, pp. 63, 74-77), abandoned due to forced relocation along the main roads by colonial administration (e.g., Brinkman, 2008, pp. 203-204). Most villages remain located along the roads, though some villagers and urban dwellers may practice agriculture in their more fertile, distant ancestral lands.

In 1961 the anti-colonial war started, and in 1963 the entire population of Zaire province took refuge in southern DRC (e.g., Mateus \& Mateus, 2011). Three years before independence Angolan refugees in DRC reached over half a million (Wheeler \& Pélissier, 1971, p. 187). The anti-colonial war ended in 1974, but the beginning of a civil war between former anti-colonial movements Movimento Popular de Libertação de Angola-MPLA (which seized power) and União Nacional para a Independência Total de Angola-UNITA (e.g., van der Waals, 2011) did not allow the immediate return of most of the refugees and internally displaced.

After the end of the civil war in 2002, the urban population increased fast due to the return of many refugees from the DRC and rural outmigration (Temudo \& Talhinhas, 2019). According to the General Census of Population and Housing conducted in 2014, the Zaire Province represented around 2.3 percent of the Angolan population, had a population density of 15 inhabitants per square kilometre, of which 73.9\% lived in urban areas (INE, 2016). The most recent estimate of the population of Mbanza Kongo reported 26577 inhabitants, ${ }^{1}$ but no reliable census data (or estimates) on the population of the surrounding villages was available. The core city centre has paved roads, concrete buildings, piped water and grid-electricity but outside it, there is an urban-rural continuum between the city districts and the villages along the main roads. After 2002, the isolation of Mbanza Kongo was reduced with the reconstruction of paved roads to Luanda capital city and Luvo (border town to the DRC). However, connections to most towns of the Zaire province (Soyo, Mandimba, Noki and Kuimba) are still underway and public transports have poor quality and are not frequent.

The farming system is rather diversified (includes several root crops, legumes, green leaves, maize, bananas and plantain and fruit trees), the staple food is cassava and the agroclimatic conditions allow two to three productions per year. This means that households practicing agriculture have not only food security, but likely some cash income to buy other essential goods and products; this is markedly different from other regions of the country where agro-ecological conditions are less favourable and the staple crop less resilient to climate change and poor soils (e. g., maize).

\section{Methodology}

\subsection{Household energy consumption empirical data collection}

The empirical data were collected — during almost nine months of

$\overline{1}$ https://www.britannica.com/place/Mbanza-Congo, last accessed 07/08/ 2018. 


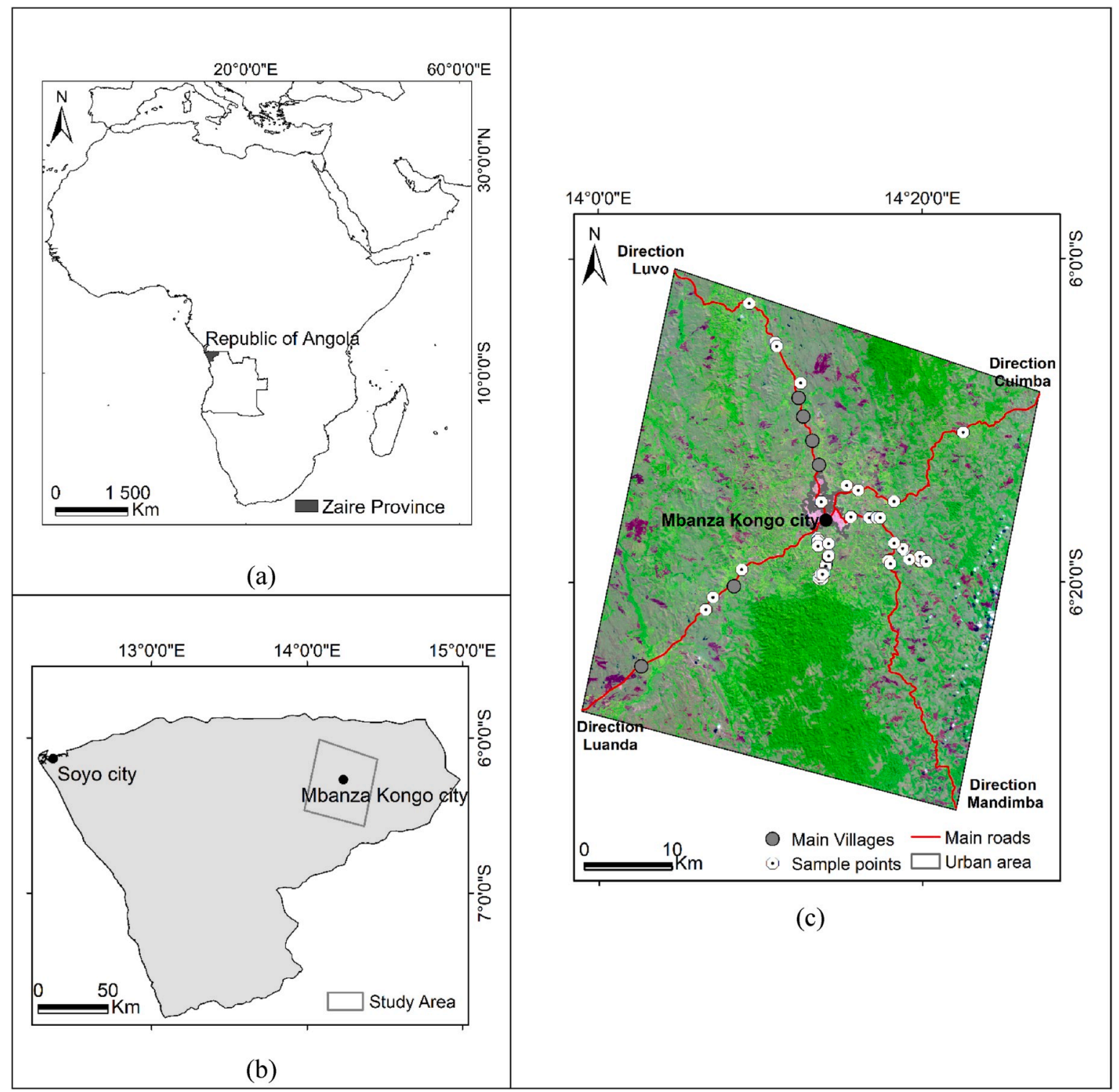

Fig. 1. (a) Location of the Zaire Province in the Republic of Angola and in the African continent, (b) Location of the study area in the Zaire province, (c) Landsat OLI (RGB 754) of 2016 color composite corresponding to the study area. (For interpretation of the references to color in this figure legend, the reader is referred to the Web version of this article.)

fieldwork and using mixed methods (e.g., Creswell \& Plano Clark, 2011) -, aiming to study the livelihood strategies adopted by poor urban and rural households after the end of the war and the role of agriculture. During three months in 2014, three hundred urban household whose agricultural fields lied in the peri-urban area (between one- and 3-h walking distance) agreed to participate and were interviewed (see Temudo \& Talhinhas, 2019, for a detailed description). In 2015 and 2016 research focused on thirty-three villages situated around Mbanza Kongo and involved three hundred and eighty-two household heads. With the exception of Kaluka (an important but isolated village linked to Mbanza Kongo through the Luanda road) and Ialangu (a rather isolated settlement located in ancestral lands, where some lived permanently and others only during the week, spending the weekends in a city house with their children), these villages were located along the roads that link Mbanza Kongo to Luvo (paved and more densely populated, being the road that links to DRC), Kuimba and Mandimba cities of Zaire province (both these roads were still in a very poor condition, though new ones were in construction) and to Luanda (the country's capital). Taking Mbanza Kongo as the centre, all villages were then progressively studied one after the other with the farthest ones in each road defining the limits of the polygon that constitutes the study area. The poor state of some main roads and the lack of public transports - the travels had to be made by taxi (either cars, motorcycles or tricycles) and on foot limited the number of sampled villages and interviewees in the less passable roads (the case of Kuimba and Mandimba roads) and/or where villages were also distant from each other (the case of Luanda, Kuimba and Mandimba roads). The Luvo road was the most populated in terms of the number of villages and distance between them, the busiest and the one along which we observed more people selling wood and mud bricks. Therefore, this is the road where more villages were studied (12 in total), only excluding the ones closest to the country's border (with more connections with DRC than with Mbanza Kongo's political economy). In villages having less than 20 households (14 villages), all heads had been interviewed. In larger villages, we randomly selected every third household and interviewed at least $15 \%$ of the household heads of each neighbourhood. No census data (or estimates) of these villages have been made available and traditional authorities were unable to provide population figures (number of inhabitants and households). Structured 
interviews to household heads (as defined by interviewees themselves) were focused on the characterization of the households in relation to gender leadership (family and farm), demographics (see Table 1), main activity and secondary occupations, date of the last return from DRC, housing and land tenure status (all of which could be used as proxy of their economic condition), farming systems and sources of energy for cooking and light. All interviews were conducted directly by the researcher either in French or Portuguese or in Kikongo (and sometimes in Lingala) with the help of a translator. A descriptive statistical analysis of this data was conducted using SPSS software (IBM Corporation Released, 2017). Unless otherwise stated, all data results from this exploratory field research.

\subsection{Land cover analysis}

Landsat Thematic Mapper (TM) and Operational Land Imager (OLI) data for 1998, 2008 and 2016 were used to analyse land cover dynamics. Data were downloaded from the United States Geological Survey ${ }^{2}$ and it was selected according to cloud cover, quality, and date of acquisition, favouring dry season and proximity to historical dates when data existed. As the fieldwork only include data collected between 2014 and 2016, the year 2016 was chosen as the final date of the analysis. The study area was covered by two Landsat scenes whose details are given in Table 2.

According to the available dates, three mosaics were composed to derive the land cover maps for the years 1998, 2008 and 2016 to have an inter-decadal analysis of the land cover dynamics. In addition, based on field knowledge and ancillary information (old vegetation maps, written descriptions of vegetation and published articles), a simplified legend of 8 land cover classes was defined: Forest, Savanna-Woodland, Grassland, Agriculture/Bare soil, Burnt, Water, Urban and Clouds. To obtain the land cover maps for each year, Landsat image mosaics were classified using the defined legend and a supervised classification technique based on the maximum likelihood classifier (Lillesand, Kiefer, \& Chipman, 2015). As Urban and Agriculture/Bare soil classes had spectral similarity values, urban area corresponding to Mbanza Kongo city was manually digitized on-screen, for each year, using Landsat TM bands 7, 4, 3 and Landsat OLI bands 7, 5, 4 combinations and the Geographic Information Systems ARCGIS 10.5.0.6491 (Environmental Systems Research Institute, ESRI 2016). To assure an accurate identification of the Mbanza Kongo city in the land cover maps, the digitized urban areas for each year were converted to the raster format and overlaid on them. Even though Landsat images were chosen according to the minimal cloud cover, each Landsat mosaic showed some clouds and clouds' shadows. Thus, they were manually digitized on-screen for each Landsat mosaic and a common mask was built and applied to each classified map to quantify the area occupied by each class. Classification accuracy for 2016 land cover map was assessed through a formal comparison between the classified image and a reference dataset. For that, a systematic grid of 1000 points with a random origin was generated upon the minimum bounding box containing the area of satellite image, and eliminating all the points located at No Data value. To collect samples for each land cover type, the systematic grid of points was overlaid on high-resolution images from Google Earth (GE), with dates between 2016 and 2018. All collected points showing date differences between the classified map and the GE high-resolution image were verified in terms of the spectral response observed in the Landsat satellite image. No validation was performed for the remaining dates, since no ground validation data or GE high-resolution images near or of the same date were available. According to Cabral et al. (2010), if the consistence of the methodology is maintained for all the period under analysis, it can be assumed that the validation accuracy of the most recent map will be enough to support validity of the historical map data set. Three accuracy measures for the

\footnotetext{
$\overline{2}$ https://earthexplorer.usgs.gov/.
}

2016 classified map were calculated - the overall accuracy, the confusion matrix and the Kappa coefficient (Foody, 2002). The Kappa coefficient is an indicator of the extent to which the correct percentage of values of a confusion matrix is due to "true" agreement versus "chance" agreement (Lillesand et al., 2015). Additionally, the four main connecting roads linking Mbanza Kongo to the above-mentioned cities (section study site) were identified and manually delimited on-screen using GE high-resolution images.

\subsection{Braiding people and pixels}

To assess the environmental impact of biomass use of poor urban and rural households practicing agriculture we compared their energy consumption patterns with land cover dynamics and the net change rates (calculated according Puyravaud, 2003) associated to Forest and Savanna-Woodland classes and Wooded-Vegetation cover (including Forest and Savanna-Woodland) in three different areas: a) the study area defined in Fig. 1, corresponding to a polygon surrounding the limits of the field work that occupied an area of 219042 ha; b) a sub-study area shown in Fig. 2, including the urban area delimited around the Mbanza Kongo city for each year plus a buffer of $10 \mathrm{~km}$, and a buffer of $5 \mathrm{~km}$ defined around the four main roads, occupying an area of $128046 \mathrm{ha}$, 129454 ha and 133508 ha for 1998, 2008 and 2016, respectively; c) a second sub-study area including the four road-areas, defined according to a buffer of $5 \mathrm{~km}$ around each road. The size of the buffers was established considering the maximum distance to the agricultural fields in the rural and urban areas. This distance is much lower in the case of rural than urban households whose members have frequently to walk over $1 \mathrm{~h}$ and a half to arrive (with a maximum of $3 \mathrm{~h}$ when they sleep in the field during some days). The comparison between land use-cover change occurred in the larger area of the polygon and the sub-study areas helped to improve accuracy in the interpretation of the data provided from different sources of information.

We performed an iterative analysis going, back and forth - across time and space - from events to possible (multiple) causes (as suggested by Walters, 2019) and from causes to events. Instead of judging households' woody biomass consumption for energy as an a priori major cause of deforestation/forest degradation we tried to identify other possible causes - whose contribution could be equally or even more relevant - , through integrating qualitative research techniques and engaging with historical events and processes. Qualitative research included informal conversations, interviews with key informants, direct observation, visits to fields and forests, interviews to rural wood sellers, market wholesalers of charcoal and grilled meat snacks.

\section{Results}

Households in Mbanza Kongo used a combination of fuels for cooking in which neither charcoal nor firewood have major importance. Table 3 shows that most of the urban households (57.3\%) mainly used kerosene stoves for cooking, firewood was adopted as a main source by $23 \%$ and charcoal by only $12.3 \%$ of the households. To note that firewood was the unique source of energy used for the time-consuming preparation of cassava flour snacks - an important source of revenue for households in which the men was head of family and farm and helped head-load to the city either the wood or the snacks prepared in the distant farms. Charcoal was used as the only or main source of energy for cooking by a reduced number of households (respectively, 7.3\% and $12.3 \%$ ). Charcoal was mostly used either for the preparation of specific dishes (e.g., grilled fish) and/or snacks to sale on the street (fried flour cakes with sugar). Gas was adopted by a minority of households as the main or sole source of energy for cooking (respectively, $7.3 \%$ and $2.7 \%)$.

The rightmost column in Table 3 shows the energy sources for cooking used by rural households. Free and easy access to firewood was translated into a high use (95.6\%), although kerosene was also used by 
Table 1

Characterization of the sample in relation to households' and farms' gender leadership and the number of household members.

\begin{tabular}{|c|c|c|c|c|c|c|c|c|}
\hline \multirow[t]{3}{*}{ Location } & \multicolumn{6}{|c|}{ Household type } & \multirow{2}{*}{\multicolumn{2}{|c|}{ Total }} \\
\hline & \multicolumn{2}{|c|}{ Man is head of family and farm } & \multicolumn{2}{|c|}{ Woman is head of family and farm } & \multicolumn{2}{|c|}{ Man is head of family and woman is head of farm } & & \\
\hline & $\% \mathrm{HH}$ & Nr. Members & $\% \mathrm{HH}$ & Nr. Members & $\% \mathrm{HH}$ & Nr. Members & $\% \mathrm{HH}$ & Nr. Members \\
\hline City & 38.3 & 6.2 & 31.6 & 5.4 & 30.0 & 6.7 & 300 & 6.1 \\
\hline Villages & 57.4 & 5.3 & 22.2 & 5.2 & 20.1 & 6.3 & 383 & 5.5 \\
\hline
\end{tabular}

Table 2

Path/Row coordinates and date of the Landsat images.

\begin{tabular}{lll}
\hline Path & Row & Date \\
\hline 182 & 64 & $05-09-1998$ \\
& & $24-03-2008$ \\
& & $18-06-2016$ \\
182 & 65 & $05-09-1998$ \\
& & $24-03-2008$ \\
& & $18-06-2016$ \\
\hline
\end{tabular}

almost one fourth of the households (24.8\%). Charcoal was only used by 27 households (7.0\%), while gas was seldom used (5 households).

The comparison of energy sources for cooking between urban and rural households also reveals that in both contexts the majority only used one source $(61.3 \%$ in the city and $73.9 \%$ in villages). However, while in the city most households in this situation either prefer kerosene $(38.0 \%)$ or firewood $(23.0 \%)$, in villages they are mostly concentrated on firewood (72.2\%). Farm residues or dung/manure were not mentioned by any informant as sources of energy and no improved cook stoves were used either in the capital city or the villages. Nonetheless, farmers mentioned that during the civil war they modified the

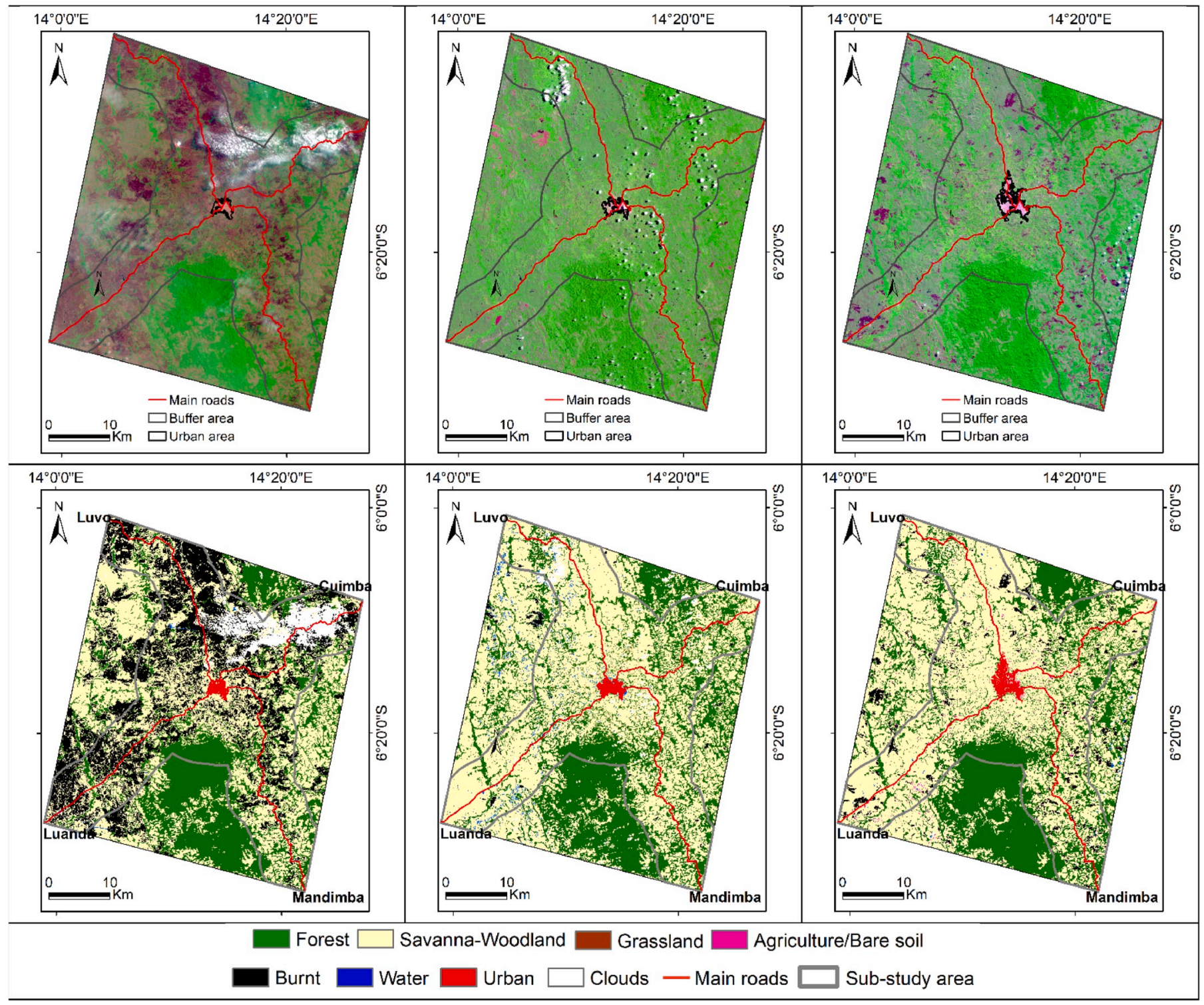

Fig. 2. Landsat TM (RGB 743) and OLI (RGB 754) and the respective land cover maps for the study area and the sub study area in 1998 (left), 2008 (middle) and 2016 (right). 
Table 3

Sources of energy for cooking in Mbanza Kongo city and in surrounding rural villages.

\begin{tabular}{lll}
\hline & City (n $=300)$ & Villages (n = 383) \\
\hline Main source of energy for cooking & & \\
Kerosene & $57.3 \%(172)$ & $4.2 \%(16)$ \\
Firewood & $23.0 \%(69)$ & $95.6 \%(366)$ \\
Charcoal & $12.3 \%(37)$ & $0.3 \%(1)$ \\
Gas & $7.3 \%(22)$ & $0 \%(0)$ \\
Main, secondary and tertiary sources of energy for cooking & \\
Kerosene, firewood and charcoal & $1.3 \%(4)$ & $3.4 \%(13)$ \\
Kerosene, firewood and gas & $0.3 \%(1)$ & $0.3 \%(1)$ \\
Kerosene, charcoal and gas & $1.0 \%(3)$ & $0 \%(0)$ \\
Kerosene and firewood only & $11.7 \%(35)$ & $16.7 \%(64)$ \\
Kerosene and charcoal only & $6.0 \%(18)$ & $0.5 \%(2)$ \\
Kerosene and gas only & $0.7 \%(2)$ & $0.3 \%(1)$ \\
Kerosene only & $38.0 \%(114)$ & $3.4 \%(13)$ \\
Firewood and charcoal only & $5.0 \%(15)$ & $2.9 \%(11)$ \\
Firewood and gas only & $1.0 \%(3)$ & $0.8 \%(3)$ \\
Firewood only & $23.0 \%(69)$ & $70.2 \%(269)$ \\
Charcoal and gas only & $1.3 \%(4)$ & $0 \%(0)$ \\
Charcoal only & $7.3 \%(22)$ & $0.3 \%(1)$ \\
Gas only & $3.0 \%(9)$ & $0 \%(0)$ \\
No use of biomass energy sources for cooking & \\
No use of firewood & $57.7 \%(173)$ & $4.4 \%(17)$ \\
No use of firewood and charcoal & $42.0 \%(126)$ & $3.7 \%(14)$ \\
\hline
\end{tabular}

traditional three stones' cook stoves (with a kind of protective wall made of mud or bricks) to reduce the production of smoke; though not intentionally, this adaptation also diminished the consumption of wood. However, according to our interviewees, this kind of improved technique to cook with wood makes them remember the privations of war times, which they would rather prefer to forget.

In relation to the main sources of energy for illumination, the analysis of the Mbanza Kongo empirical data reveals that the majority of households used kerosene lamps (Table 4), but a relatively high percentage had access to electricity (43.7\%), either provided by the municipality and/or their generators (21.4\%). Dry cell batteries' lamps (flashlights) were seldom used. On the contrary, in rural villages the use of kerosene lamps is much lower (30.4\%) and that of flashlights is high (52.4\%). In rural villages, $95.7 \%$ of those households who had access to electricity had been able either to buy their generator or to divide the running costs with relatives/neighbours who had one. The government has also provided a few villages with grid-electricity, where families only had to pay for the costs of the grid connections to their homes and the municipality oversaw the running costs, but their working is irregular. No candles and/or solar photovoltaic lanterns were ever mentioned by any urban interviewee. Although bonfires are commonly lit at down and constitute a source of heating and light in villages, firewood was never mentioned by any interviewee as a source of energy for lighting. The analysis of Tables 3 and 4 also reveals for both city and villages that while for cooking a high percentage of households use a mix of energy sources, for lighting they prefer to use one.

Firewood used for cooking in rural villages mostly comprises dead wood, branches and biomass derived from shifting cultivation and orchard creation, which can include Chromolaena odorata trunks. However, deforestation for firewood may be conducted when the aim is to supply the urban bakeries and/or to burn mudbricks for housebuilding, especially when it is a market-oriented activity conducted by men during the dry season. Similarly, in occasional production of charcoal for selling, the wood used is usually resultant from deforestation aimed to create orchards; nevertheless, in the case of farmers who do that as a regular source of income during the dry season, the wood comes from live mature trees slashed in more distant forests. Table 5 displays the engagement in income-earning activities related to deforestation and/or forest degradation of urban and rural households. The data shows that only few urban households sold wood (16.7\%); additionally, direct observations revealed that only dead wood was used for this purpose and that this was a rather irregular activity of household members. Surprisingly, in rural areas fewer households were engaged in this activity (10.7\%), but around $10 \%$ used to sell mudbricks and $20.4 \%$ produced charcoal for the urban market; nonetheless, this data does not include deforestation created by the production of mudbricks used in the construction of their homes. In more densely populated areas, people engaged in charcoal or mudbricks production for sale frequently had to buy the wood to traditional authorities (named Mfumu Nsanda in Kikongo), who are considered the owners of the surrounding forests; but in isolated forested locations (along Kuimba road, mostly), access to wood is free and men involved in charcoal production or timber extraction may have their chainsaws or work for an urban employer (who provides them with the tools, petrol and food and pays monthly according to the quantity of the timber cut). Some traditional authorities are also engaged directly in the sale of firewood or timber in collaboration with urban actors who come to rural areas; in these cases, concerns have been raised by some interviewees about the unsustainable management and likely future woodfuel scarcity for local users.

The analysis of the land cover maps for 1998, 2008 and 2016 and the corresponding land cover changes can be observed in Figs. 2 and 3, respectively. As explained above, only the accuracy of the 2016 land cover map was evaluated; the values obtained for the overall accuracy and Kappa coefficient, concordance, omission and commission errors, and number of pixels are shown in Table 6. Values show a high agreement level of the classification with the validation dataset. Accuracy for Forest and Savanna Woodland classes is above $90 \%$, with low omission and commission errors. The classes Agriculture/Bare soil and Burnt present high omission errors, particularly the last one, resulting from an incorrect assignment of the pixels to the Savanna Woodland class. As burnt mainly occur in Savanna Woodland, it may exist some spectral confusion if the fire scar is not recent. Grassland was not evaluated as no points in the grid were located in this class.

The almost two decades of observation reveal that for both the study and sub-study areas, woody vegetation increased between 1990 and 2008 and slightly decreased during the second period; additionally, there was no visible change in the two compact areas of forest located in

Table 5

Households engaged in firewood, charcoal and mudbricks selling, and that have access to forest and plant orchards in Mbanza Kongo city and in rural villages.

\begin{tabular}{lllll}
\hline Location & Product sold & & $\begin{array}{l}\text { Have access to forest and } \\
\text { plant fruit trees }\end{array}$ \\
\cline { 2 - 4 } & Firewood & Charcoal & Bricks & \\
\hline City & $16.7 \%(\mathrm{n}=$ & $0.3 \%(\mathrm{n}=$ & $0 \%(\mathrm{n}=$ & $46.0 \%(\mathrm{n}=138)$ \\
& $50)$ & $1)$ & $0)$ & \\
Villages & $10.7 \%(\mathrm{n}=$ & $20.4 \%(\mathrm{n}=$ & $\begin{array}{l}9.9 \%(\mathrm{n}= \\
38)\end{array}$ & $46.5 \%(\mathrm{n}=178)$ \\
& $41)$ & $78)$ & $38)$ & \\
\hline
\end{tabular}

Table 4

Main sources of energy for illumination in Mbanza Kongo city and in rural villages.

\begin{tabular}{|c|c|c|c|c|c|c|}
\hline \multirow[t]{2}{*}{ Location } & \multicolumn{6}{|l|}{ Sources of energy } \\
\hline & Electricity (main) & Kerosene (main) & Flashlight (main) & $\begin{array}{l}\text { Electricity+ } \\
\text { Kerosene }\end{array}$ & $\begin{array}{l}\text { Electricity+ } \\
\text { Flashlight }\end{array}$ & $\begin{array}{l}\text { Kerosene+ } \\
\text { Flashlight }\end{array}$ \\
\hline City & $43.7 \%(131)$ & $53.3 \%$ (159) & $3.0 \%(9)$ & $2.3 \%(7)$ & $0 \%(0)$ & $0.3 \%(1)$ \\
\hline Villages & $30.4 \%(116)$ & $16.8 \%(64)$ & $52.4 \%(200)$ & $2.1 \%(8)$ & $3.7 \%(14)$ & $2.1 \%(8)$ \\
\hline
\end{tabular}




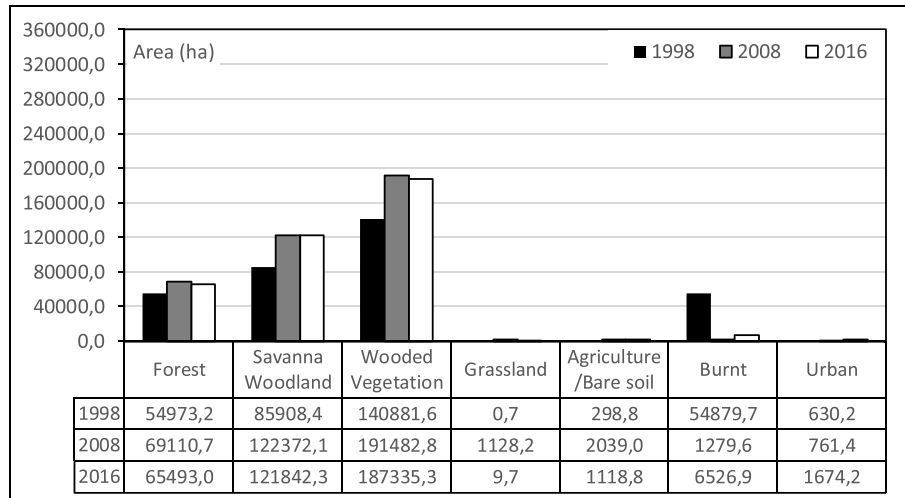

(a)

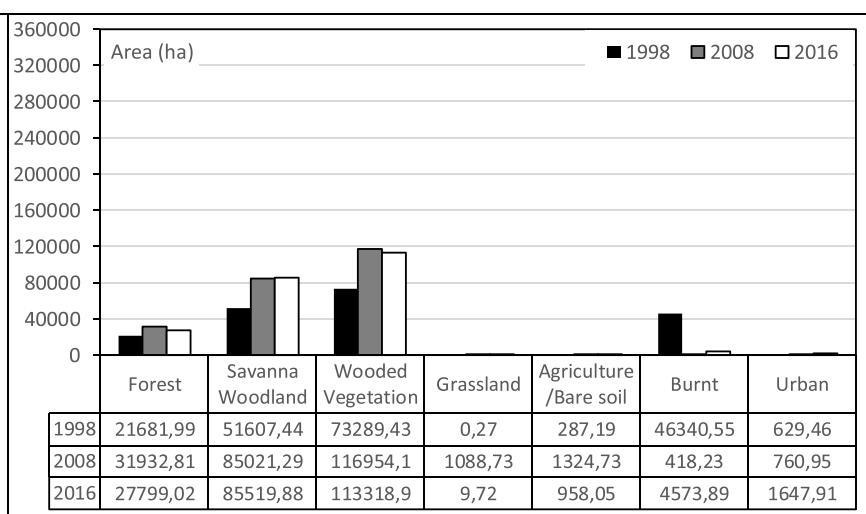

(b)

\begin{tabular}{lllcc}
\hline \multicolumn{1}{c}{ Period } & \multicolumn{1}{c}{ Class type } & $\mathbf{1 9 9 8 - 2 0 0 8}$ & $\mathbf{2 0 0 8 - 2 0 1 6}$ & $\mathbf{1 9 9 8 - 2 0 1 6}$ \\
\cline { 1 - 4 } Change rate (\%yr-1) & & & & \\
\hline \multirow{3}{*}{ Study Area } & Forest & 2.29 & -0.67 & 0,97 \\
\cline { 2 - 5 } & Savanna Woodland & 3.54 & -0.05 & 1.94 \\
\cline { 2 - 5 } Wooded Vegetation & 3.07 & -0.27 & 1.58 \\
\hline \multirow{3}{*}{ Sub-Study Area } & Forest & 3.87 & -1.73 & 1.38 \\
\cline { 2 - 5 } & Savanna Woodland & 4.99 & 0.07 & 2.81 \\
\cline { 2 - 5 } & Wooded Vegetation & 4.67 & -0.39 & 2.42 \\
\hline
\end{tabular}

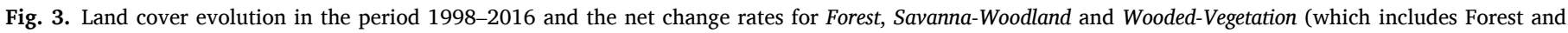

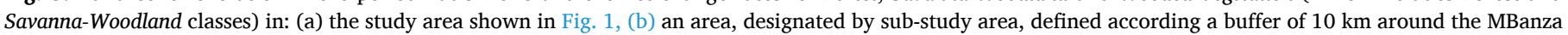
Kongo city and a buffer of $5 \mathrm{~km}$ around the main roads.

Table 6

Results of the classification accuracy assessment for 2016.

\begin{tabular}{lllll}
\hline $\begin{array}{l}\text { Land cover } \\
\text { class } \\
\text { Classification }\end{array}$ & $\begin{array}{l}\text { Concordance } \\
(\%)\end{array}$ & $\begin{array}{l}\text { Omission } \\
\text { error }(\%)\end{array}$ & $\begin{array}{l}\text { Commission } \\
\text { error }(\%)\end{array}$ & $\begin{array}{l}\text { Number of } \\
\text { pixels }\end{array}$ \\
\hline $\begin{array}{l}\text { Forest } \\
\text { Savanna } \\
\quad \text { Woodland }\end{array}$ & 91.7 & 8.3 & 0.5 & 216 \\
$\begin{array}{l}\text { Grassland } \\
\text { Agriculture/ }\end{array}$ & 0.0 & 0.6 & 10.2 & 364 \\
$\quad$ Bare soil & 75.0 & 0.0 & 0.0 & 0 \\
$\begin{array}{l}\text { Burnt } \\
\text { Urban }\end{array}$ & 63.8 & 25.0 & 0.0 & 4 \\
\hline $\begin{array}{l}\text { OA }=93.4 \% K \\
\quad 100.0\end{array}$ & 36.2 & 0.0 & 58 \\
\hline
\end{tabular}

the north (between Luvo and Kuimba roads) and south (between Luanda and Mandimba roads) of Mbanza Kongo city. This means that the expansion of the city and the growing urban demand for biomass as a source of energy (both for cooking, lighting and house building) did not have a high impact on deforestation. INE, 2016, for the study and sub-study areas, the Wooded-Vegetation (including the classes of Forest and Savanna-Woodland) occupied an area about 33\% and 55\% larger than in 1998, respectively (corresponding to an annual change rate of 1 , $58 \%$ and $2,42 \%$, respectively).

Nonetheless, Fig. 3 shows that this increase occurred during the first period (1998-2008), followed by a decrease until 2016 in the area occupied by both classes and, consequently, a net loss in the woody vegetation. The decrease in the Forest and Wooded Vegetation classes is more pronounced for the sub-study area as shown in Fig. 3, although it presented a higher increase in the first period. In the ring around the city and the band along the roads (sub-study area) the behaviour of the Forest and Wooded-Vegetation classes was similar in 2008-2016, but the Savanna-Woodland class showed a slight net increase at the expense of a decrease in the Forest class.

Land cover changes, during the whole period comprised between 1998 and 2016, along the four main roads that depart from Mbanza Kongo city (Fig. 4) all present a net gain in Forest and Wooded-Vegetation, with Luvo road showing the higher values $(3.98 \%$ and $4.19 \%$, respectively). However, when we analyse the two periods separately, all roads present a regeneration trend during the first period (1998/2008), and a deforestation/forest degradation trend during the second period (2008-2016). Kuimba road exhibits the highest Forest net loss (with an annual change rate of $-3.55 \%$ ) and Mandimba road the higher WoodedVegetation net loss (annual change rates of $-0.73 \%$ ). Kuimba is also the road showing the highest net increase of the class Savanna Woodland, while Mandimba is the only road in which this class decreases.

\section{Discussion, conclusions and policy recommendations}

So far, the Angolan economy has been almost totally reliant on oil extraction and export (Pearce, Péclard, \& Soares de Oliveira, 2018, p. 159). However, the country's refinery capacity is still low and even though most oil-based products are imported, its price has been subsidized by the government (IEA, 2006). Contrary to what has been reported for other Angolan cities (e.g., IEA, 2006, p. 141; Cornelio, 2009; Cabral et al., 2010), in Mbanza Kongo and its surrounding villages this policy has had the effect of favouring the use of kerosene as a source of energy, although its effect is most visible in the city. This fact, nonetheless, does not support either the "energy ladder" model (e.g., Barnes \& Floor, 1996), or the "multiple fuel" one (Masera et al., 2000); following arguments raised by Hiemstra-van der Horst and Hovorka (2008), it illustrates the importance of consumer choice of their energy-use patterns and multiple-fuel mixes, but also shows that the 


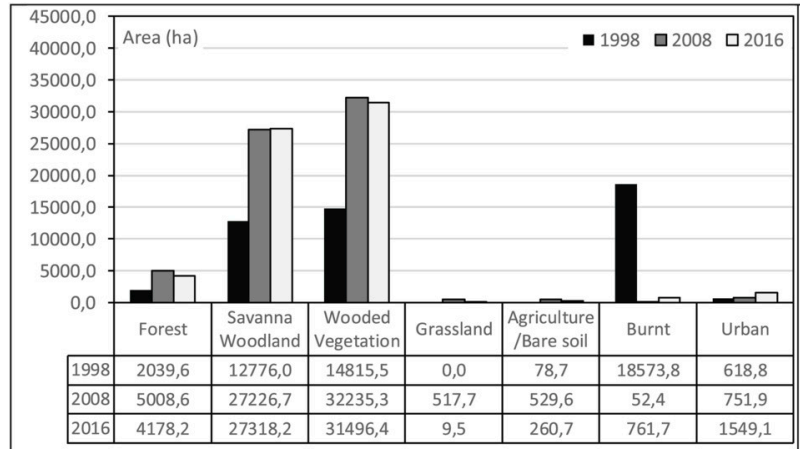

Luvo road

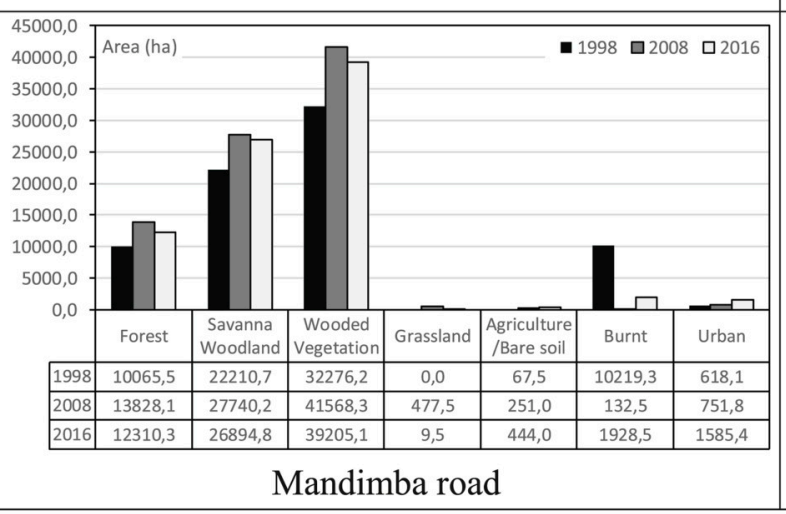

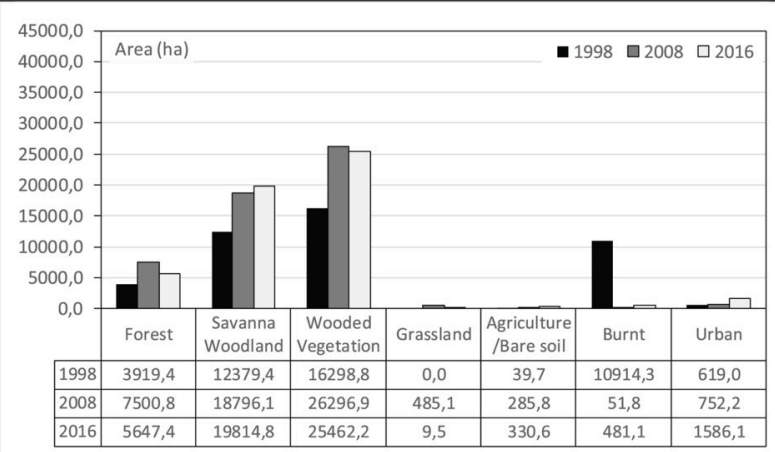

Kuimba road

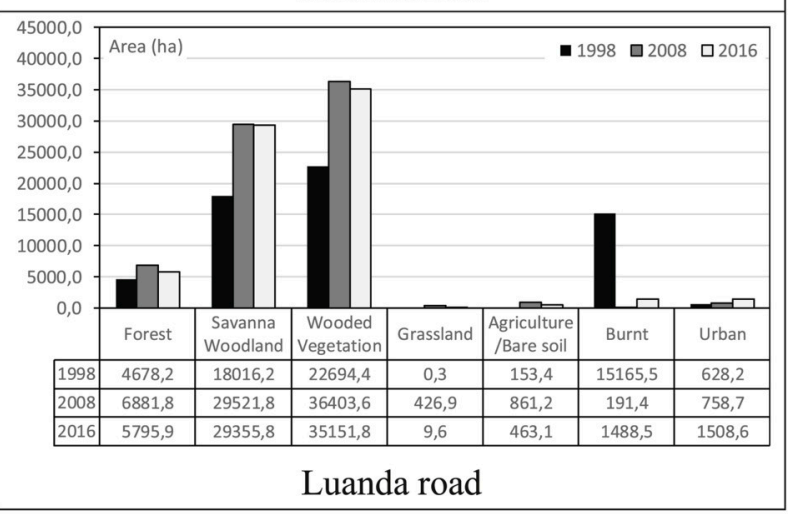

\begin{tabular}{|c|c|c|c|c|}
\hline Period & Class type & 1998-2008 & 2008-2016 & 1998-2016 \\
\hline \multicolumn{5}{|l|}{ Change rate $\left(\% \mathrm{yr}^{-1}\right)$} \\
\hline \multirow{3}{*}{ Luvo road } & Forest & 8.98 & -2.27 & 3.98 \\
\hline & Savanna-Woodland & 7.57 & 0.04 & 4.22 \\
\hline & Wooded-Vegetation & 7.77 & -0.29 & 4.19 \\
\hline \multirow{3}{*}{ Kuimba road } & Forest & 6.49 & -3.55 & 2.03 \\
\hline & Savanna-Woodland & 4.18 & 0.66 & 2.61 \\
\hline & Wooded-Vegetation & 4.78 & -0.4 & 2.48 \\
\hline \multirow{3}{*}{ Mandimba road } & Forest & 3.18 & -1.45 & 1.12 \\
\hline & Savanna-Woodland & 2.22 & -0.39 & 1.06 \\
\hline & Wooded-Vegetation & 2.53 & -0.73 & 1.08 \\
\hline \multirow{3}{*}{ Luanda road } & Forest & 3.86 & -2.15 & 1.19 \\
\hline & Savanna-Woodland & 4.94 & -0.07 & 2.71 \\
\hline & Wooded-Vegetation & 4.73 & -0.44 & 2.43 \\
\hline
\end{tabular}

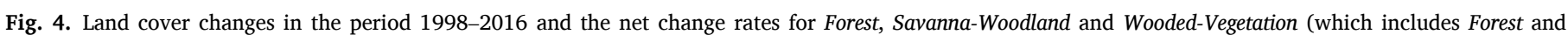
Savanna-Woodland classes) in the four road-areas around Mbanza Kongo. The analysis was performed in a buffer of 5 km built around the roads.

majority of households are not "stuck" to firewood or charcoal used for cooking (Masera et al., 2000). Indeed, despite the price of oil-based products has been subsidized and may have contributed to the widespread urban use of kerosene, consumers did not move in a kind of evolutionary manner from fuelwood to more modern fuel options. Additionally, firewood did not become an integral component of the households' energy mix, nor did charcoal become the "transition fuel" (Zulu \& Richardson, 2013) to which households switch first after abandoning firewood.

Contrary to the findings of other scholars (e.g., Shackleton, Gambiza, \& Jones, 2007), our direct observations showed that households that collected their supplies of fuelwood were not poorer than the ones that used kerosene, charcoal or even gas. The persistence of firewood use among some urban households cannot be explained by poverty per seand even less by its availability considering the distance from home of the majority of agricultural fields and savannas/woodlands -, but as a strategic decision taken by household heads in order to save money for other goals (as also noted by Hiemstra-van der Horst \& Hovorka, 2008, p. 3341). Moreover, some of the urbanites that used to sell firewood were not using it in their households. To note that, firewood is mostly used in the processing of cassava for selling and by farmers who cook in the field when they spend the day working there (mostly couples). The low use of firewood in the city has a cultural determinant which similarly applies to the non-adoption of "improved" firewood cook stoves in rural areas, as both are associated by our interviewees to the hardships of the civil war. Another cultural determinant of some fuel-mix strategies is the fact that certain food processing activities are associated with specific energy sources (e.g., grilled fish and fried snacks for urban street selling with charcoal; grilled chicken for urban markets selling with firewood; cassava processing for selling with firewood). This means that 
the different fuels are not viewed as fully interchangeable, but also that price differences are taken into account in some cases (e.g., kerosene versus gas in general; kerosene versus firewood in the case of cassava long cooking processing; charcoal versus the other fuels in the case of certain dishes) - all of which support the findings of Hiemstra-van der Horst and Hovorka (2008) and Clancy (2008: 467) in other contexts. In the villages, the consumption of biomass for cooking was high, probably due to fuelwood availability in nearby fields and forests, and the more difficult access and higher retail prices of kerosene.

Fuel mixes were seldom used in the case of lighting, both in the city and rural villages; but while in the city household heads prefer kerosene lamps, in rural areas they prefer dry cell batteries' lamps. To note that, in the studied area, access to electricity is higher than the one reported for the country (UNEP 2013). The majority of households aimed at buying a generator to be able to have electricity, not only to light their houses but also to have a television and a fridge and/or a freezer; their saving strategy, though, frequently included the use of firewood for cooking.

Firewood mostly consisted of dead wood, branches and/or was resultant from agriculture; thus, not directly causing deforestation or forest degradation, as observed in the analysis of land cover changes through remote sensing. When the slashed biomass consisted of mature trees, these were not usually used either as urban or rural domestic fuelwood but sold for the urban bakery industry (large trunks), the urban-markets' sellers of grilled chicken (tree branches) or to produce charcoal or bricks (large trunks) for the urban market. However, we found some villages where charcoal and/or brick production or firewood harvesting for the urban market were being conducted as important economic activities independent of agriculture. Firewood can be free and easy to gather in rural areas, but it is difficult to ignite during the rainy season, which explains the use of a complementary source; some also preferred to use kerosene (and even gas in villages close to the city) given the absence of smoke and its perceived connection with a higher social status. Charcoal production also demands the availability of mature trees, lots of labour and is a good and quick source of cash income for farmers who produce it (though it also implies many days of hard work). According to our interviewees, while in order to build a house with the selling of agricultural products farmers need to save during three years, charcoal provides in only one year the necessary cash for buying the materials and paying for labour or the items (e.g., drinks) needed to call for the support of friends and family.

As so, if most poor urban dwellers were not causing deforestation through their household use of biomass as a source of domestic energy by the one hand, by the other the house building techniques of both urban and rural dwellers together with the urban food industry are becoming a source of forest degradation and deforestation, which starts to be visible after 2008, when a second wave of the refugees in DRC returned to Angola. The largest deforestation is not occurring among the most populated, provided with more transports and paved roads of Luvo and Luanda (that stand in the second and third positions), but in the Kuimba road where the highest increase in the savanna woodland class also occurs. Indeed, Kuimba was precisely the road where we could find poachers cutting timber in isolated forested locations in which access was free. On the contrary, the case of the Mandimba road is the only one where deforestation is occurring together with a decrease in the Savanna Woodland class, which highlights that the construction of the new road seems to be another driver of deforestation. Additionally, deforestation is also occurring in the less accessible areas of the study area, although at a slower pace than in the sub-study area where access to roads and transports is easier. These are places where poachers do not have to get permission from local authorities and can stay for days producing charcoal to sell in Mbanza Kongo; contrary to timber or fuelwood, charcoal is light and can be head-loaded up to the roads. Charcoal production by farmers living in the sub-study area was considered a hard activity that only a few young men wanted to pursue, generally as a short-term endeavour (e.g., to get cash to buy a generator or built a good house). Another lucrative and fuelwood-consuming activity conducted by farmers, when their fields are located near to watercourses and forests, is the production of sugarcane and its liquor. But again, the lack of rural roads is a constraint to the full development of the activity and a major impact in terms of deforestation.

Considering that some of the alternatives are not cleaner than biomass burning, several scholars have been advocating the support for firewood production in developing countries through managed fuelwood harvesting and agroforestry systems (e.g., Ndayambaje \& Mohren, 2011; Wangchuk, Siebert, \& Belsky, 2014). Indeed, petroleum-based products contribute to air pollution, global climate change and the exhaustion of non-renewable resources, making urgent the adoption of clean energy sources (Agoramoorthy \& Hsu, 2009; Clancy, 2008; Tenerelli \& Carver, 2012). Most grid-electricity in Angola comes from hydropower, which is also a source of environmental degradation (IEA, 2006, p. 79) and the private and public rural electrification in Zaire province was based on diesel or petrol generators. The availability of petroleum-based products with a subsidized price may explain the relatively high use of electricity in the province. To note, however, that most of the interviewees had their generator, which was only possible to buy through selling agricultural products, charcoal or mudbricks and because food self-sufficiency was guaranteed by agricultural production.

In addition to oil, diamonds, and hydropower, Angola has also a huge potential to produce renewable energy from wind and sun. Lowemissions development strategies (LED) would then be easy to implement, help reduce "energy-poverty" (e.g., Li, Lloyd, Liang, \& Wei, 2014), contribute to mitigate climate change - through reducing greenhouse gases (GHG) emissions and increasing carbon stocks -, and allow a cleaner economic development in an oil-dependent economy. Until this (unrealistic in the short-medium term) move forward becomes possible and alternatives to mud-bricks technology are developed, and bearing in mind that some households still include biomass in their multiple-fuel mixes, more attention should be paid to support the introduction of multi-purpose trees (implying woodfuel production) in agroforestry systems and of more efficient cook stoves - which would also contribute to improving poor people's livelihoods.

\section{Statement}

This manuscript has not been previously published and it is not under review for publication elsewhere. Its publication has been accepted by all authors, and tacitly by the responsible authorities of the University of Lisbon. The authors also declare that, if accepted, the article will not be published elsewhere in any form without the consent of the copyright-holder.

\section{Declaration of competing interest}

No potential conflict of interest was reported by the authors.

\section{CRediT authorship contribution statement}

Marina Padrão Temudo: Writing - original draft. Ana I.R. Cabral: Formal analysis, Writing - original draft, Methodology. Pedro Talhinhas: Formal analysis.

\section{Acknowledgements}

Research in Angola was conducted within the framework of the AHRC project "Heritage and Landscapes Transformation in Northern Angola: Between the Value of the Past and the Value of the Land", partner of the Joint Research Programme "Currents of Faith, Places of History" and funded by the EU consortium HERA (Humanities European Research Area) in 2013-2016. In Angola we would like to thank all the people who kindly accepted to collaborate in this research, Professor Fátima Viegas, Dr Luís Viegas and Paulo and Carlos Monteiro, Frei Danilo of the Capuchin mission for their support, our translators Lando (Grandão) and 
Blaise Matondo. Acknowledgments are also due to Bruno Máximo with whom we shared ideas, data and references and to José Miguel Cardoso Pereira for important comments to the manuscript. CEF and LEAF are research units funded by Fundação para a Ciência e a Tecnologia I.P. (FCT), Portugal (grants UIDB/00239/2020 and UIDB/04129/2020, respectively).

\section{References}

Adkins, E., Oppelstrup, K., \& Modi, V. (2012). Rural household energy consumption in the millennium villages in Sub-Saharan Africa. Energy for Sustainable Development, 16 (3), 249-259.

Agoramoorthy, G., \& Hsu, M. (2009). Lightening the lives of the impoverished in India's rural and tribal drylands. Human Ecology, 37, 513-517.

Atyi, E., Poufun, N., Mvondo-Awono, J., Ngoungoure, A., \& Sufu, R. (2016). Economic and social importance of fuelwood in Cameroon. International Forestry Review, 18, 52-65.

Barnes, D., \& Floor, W. (1996). Rural energy in developing countries: A challenge for economic development. Annual Review of Energy and the Environment, 21, 497-530.

Bildirici, M., \& Özaksoy, F. (2016). Woody biomass energy consumption and economic growth in Sub-Saharan Africa. Procedia Economics and Finance, 38, 287-293.

Bone, R. A., Parks, K. E., Hudson, M. D., Tsinrinzeni, M., \& Willcock, S. (2017). Deforestation since independence: A quantitative assessment of four decades of landcover change in Malawi. Southern Forests, 79(4), 269-275.

Brinkman, I. (2008). Refugees on route. Congo/Zaire and the war in northern Angola (1961-1974). In B. Heintze, \& A. Oppen (Eds.), Angola on the move. Transport routes, communications and history (pp. 198-220). Frankfurt: Lembeck.

Cabral, A., Vasconcelos, M. J., Oom, D., \& Sardinha, R. (2010). Spatial dynamics and quantification of deforestation in the central-plateau woodlands of Angola. Applied Geography, 31(3), 1185-1193.

Cain, A. (2007). Housing microfinance in post-conflict Angola: Overcoming socioeconomic exclusion through land tenure and access to credit. Environment and Urbanization, 19(2), 361-390.

Castanheira Diniz, A. (2006). Características mesológicas de Angola. Lisboa: IPAD.

Chiteculo, V., Hájek, M., \& Kubová, P. (2018). Production and commercialization of timber in Angola after the declaration of independence. Scientia Agriculturae Bohemica, 49(1), 38-45.

Clancy, J. S. (2008). Urban ecological footprints in Africa. African Journal of Ecology, 46 (4), 463-470.

Cornelio, F. (2009). Energy-poverty and its impacts on peri-urban zones of Huambo city, Angola. Master dissertation. Lund: Lund University.

Creswell, J., \& Plano Clark, V. (2011). Designing and conducting mixed methods research. Thousand Oaks, California: BMJ Publishing Group.

Environmental Systems Research Institute (ESRI). (2016). ArcGIS desktop 10.5, version 0.5.0.6491 (Redlands, CA)

Foody, G. M. (2002). Status of land cover classification accuracy assessment. Remote Sensing of Environment, 80, 185-201.

Godfrey, A., Denis, K., Daniel, W., \& Akais, O. (2010). Household firewood consumption and its dynamics in Kalisizu sub-county, Central Uganda. Ethnobotanical Leaflets, 14, $841-855$.

Guild, J., \& Sheckleton, C. (2018). Informal urban fuelwood markets in South Africa in the context of socioeconomic change. Energy Policy, 117, 136-141.

Hansfort, S. L., \& Mertz, O. (2011). Challenging the woodfuel crisis in West African woodlands. Human Ecology, 39(5), 583e595.

Hiemstra-van der Horst, G., \& Hovorka, A. (2008). Reassessing the "energy ladder": Household energy use in maun, Botswana. Energy Policy, 36(9), 3333-3344.

Hiemstra-van der Horst, G., \& Hovorka, A. (2009). Fuelwood: The 'other' renewable energy source for Africa? Biomass and Bioenergy, 33(11), 1605-1616.

IBM Corporation Released. (2017). IBM SPSS statistics for windows, version 25.0. Armonk, NY: IBM Corp.

Iea. (2006). Angola: Towards an energy strategy. Paris: OEC JC D.

INE. (2016). Censo 2014: Resultados definitivos do recenseamento geral da população e habitação de Angola. Luanda: Instituto Nacional de Estatística.

Konga, R., Diepartb, J. C., Castellac, J. C., Lestrelinc, G., Tivetc, F., Belmainc, E., et al. (2019). Understanding the drivers of deforestation and agricultural transformations in the Northwestern uplands of Cambodia. Applied Geography, 102, 84-98.

Lillesand, T., Kiefer, R. W., \& Chipman, J. (2015). Remote sensing and image interpretation (7th ed.). New York: Wiley.

Li, K., Lloyd, B., Liang, X. J., \& Wei, Y. M. (2014). Energy poor or fuel poor: What are the differences? Energy Policy, 68, 476-481.

Liverman, D., Moran, E., Rindfus, R., \& Stern, P. (Eds.). (1998). People and pixels: Linking remote sensing and social science. Washington, DC: National Academy Press.

Masera, O., Saatkamp, B., \& Kammen, D. (2000). From linear fuel switching to multiple cooking strategies: A critique and alternative to the energy ladder model. World Development, 28(12), 2083-2103.

Mateus, D., \& Mateus, A. (2011). Angola 61. Guerra colonial: Causas e consequências. Alfragide (Texto Ed).

Mulenga, B., Tembo, S., \& Richardson, R. (2019). Electricity access and charcoal consumption among urban households in Zambia. Development Southern Africa, 36 (5), 585-599.
Ndayambaje, J., \& Mohren, G. (2011). Fuelwood demand and supply in Rwanda and the role of agroforestry. Agroforestry Systems, 83(3), 303-320.

Odihi, J. (2003). Deforestation in afforestation priority zone in Sudano-Sahelian Nigeria. Applied Geography, 23, 227-259.

Pearce, J., Péclard, D., \& Soares de Oliveira, R. (2018). Angola's elections and the politics of presidential succession. African Affairs, 117(466), 146-160.

Puyravaud, J.-P. (2003). Standardizing the calculation of the annual rate of deforestation. Forest Ecology and Management, 177(1-3), 593-596.

Ribot, J. (1999). A history of fear: Imagining deforestation in west african dryland forests. Global Ecology and Biogeography, 8(3-4), 291-300.

Sambou, S., Lykke, A., Sambou, H., Guiro, I., Sambou, B., \& Mbow, C. (2015). Land useland cover change and drivers of deforestation in the patako protected area (CenterWest of Senegal). American Journal of Environmental Protection, 4(6), 306-317.

Schlesinger, J., Drescher, A., \& Shackleton, C. (2015). Socio-spatial dynamics in the use of wild natural resources: Evidence from six rapidly growing medium-sized cities in Africa. Applied Geography, 56, 107-115.

Schure, J., Levang, P., \& Wiersum, F. (2014). Producing woodfuel for urban centers in the democratic republic of Congo: A path out of poverty for rural households? World Development, 64(Supplement 1), S80-S90.

Shackleton, C., Gambiza, J., \& Jones, R. (2007). Household fuelwood use in small electrified towns of the Makana District, Eastern Cape, South Africa. Journal of Energy in Southern Africa, 18(4), 4-10.

Soussan, J., O'Keefe, P., \& Munslow, B. (1990). Urban fuelwood: Challenges and dilemmas. Energy Policy, 18(6), 572-582.

Stoppok, M., Jess, A., Freitag, R., \& Erdmute, A. (2018). Of culture, consumption and cost: A comparative analysis of household energy consumption in Kenya, Germany and Spain. Energy Research and Social Science, 40, 127-139.

Swemmer, A., Mashele, M., \& Ndhlovu, P. (2019). Evidence for ecological sustainability of fuelwood harvesting at a rural village in South Africa. Regional Environmental Change, 403-413.

Tadesse, G., Zavaleta, E., Shennan, C., \& FitzSimmons, M. (2014). Policy and demographic factors shape deforestation patterns and socio-ecological processes in southwest Ethiopian coffee agroecosystems. Applied Geography, 54, 149-159.

Temudo, M. P., \& Talhinhas, P. (2019). Dynamics of change in a "female farming system", Mbanza Kongo/Northern Angola. Journal of Peasant Studies, 46(2), $258-275$.

Tenerelli, P., \& Carver, S. (2012). Multi-criteria, multi-objective and uncertainty analysis for agro-energy spatial modelling. Applied Geography, 32, 724-736.

UNEP-RIS $\varnothing$ Centre. (2013). Emissions reduction profile Angola. http://www.acp-cd4 cdm.org/media/362934/emissions-reduction-profile-angola.pdf. last accessed June 2018.

Vollmer, F., Zorrilla-Miras, P., Baumert, S., Luz, A., Woollen, E., Grundy, I., et al. (2017). Charcoal income as a means to a valuable end: Scope and limitations of income from rural charcoal production to alleviate acute multidimensional poverty in malabane disctrict, southerm Mozambique. World Development Perspectives, 7-8, 43-60.

van der Waals, S. (2011). Portugal's war in Angola 1961-1974. Pretoria: Protea Book House.

Walters, B. (2019). The greening of Saint Lucia: Economic and environmental change in the eastern caribbean. Mona: The University of West Indies Press.

Wangchuk, S., Siebert, S., \& Belsky, J. (2014). Fuelwood use and availability in Bhutan: Implications for national policy and local forest management. Human Ecology, 42(1), $127-135$.

Waroux, Y., \& Lambin, E. (2012). Monitoring degradation in arid and semi-arid forests and woodlands: The case of the argan woodlands (Morocco). Applied Geography, 32, 777-786.

Wheeler, D., \& Pélissier, R. (1971). Angola. NY: Praeger Publishers.

Zulu, L., \& Richardson, R. (2013). Charcoal, livelihoods and poverty reduction: Evidence from sub-saharan Africa. Energy for Sustainable Development, 17(12), 127-137.

Marina Padrão Temudo is a senior research fellow at CEF, School of Agriculture, University of Lisbon, Portugal. She has conducted extensive ethnographic field research on development and conservation in Guinea-Bissau, Angola, Cape Verde, Mozambique, S. Tomé and Príncipe, and in the Republic of Guinea. Some of her most recent articles have been published in Human Ecology, Journal of Peasant Studies, Development and Change, the Journal of Agrarian Change, Agroforestry Systems and Conservation \& Society.

Ana I.R. Cabral is a senior research fellow at CEF, School of Agriculture, University of Lisbon, Portugal. She is a Remote Sensing and Geographic Information System expert, working in tropical regions, mainly in African countries and Brazil, in the areas of deforestation and forest degradation, mapping and modeling of land cover/land use change scenarios, quantification of carbon emissions and landscape fragmentation. Her most recent articles have been published in Applied Geography, ISPSR Journal of Photogrammetry and Remote sensing and Swarm and Evolutionary Computation Journal.

Pedro Talhinhas is a research fellow at LEAF, School of Agriculture, University of Lisbon, Portugal. He has conducted work on Plant Genetic Resources, Plant Breeding, Plant Pathology and Mycology. Some of his most recent articles have been published in Molecular Plant Pathology, PLoS One, Plant Disease, Frontiers in Plant Science and Plant Pathology. 